\title{
Eosinophilia Associated With The Use Of Carfilzomib In A Patient With Multiple Myeloma: A Case Report and review of literature
}

\author{
Viera Sandecka ${ }^{1}$ and Ludek Pour ${ }^{2}$ \\ ${ }^{1}$ University Hospital Brno Internal hematology and oncology clinic \\ ${ }^{2}$ Fakultni Nemocnice Brno
}

July 23, 2020

\begin{abstract}
Multiple myeloma had been an incurable hematological malignancy, recent advances in novel anti-neoplastic agents, including carfilzomib (CFZ), have improved the prognosis. CFZ has been reported to have cardiotoxic effects. Notably, the incidence of peripheral blood eosinophilia was not described. This is the first report of eosinophilia developing after CFZ.
\end{abstract}

\section{Hosted file}

Title_page_for_case_report (1).doc available at https://authorea.com/users/345391/articles/ 471631-eosinophilia-associated-with-the-use-of-carfilzomib-in-a-patient-with-multiplemyeloma-a-case-report-and-review-of-literature

\section{Hosted file}

Hypereosinofilia-_main_document-_final_version_(1).docx available at https://authorea.com/ users/345391/articles/471631-eosinophilia-associated-with-the-use-of-carfilzomib-in-apatient-with-multiple-myeloma-a-case-report-and-review-of-literature 


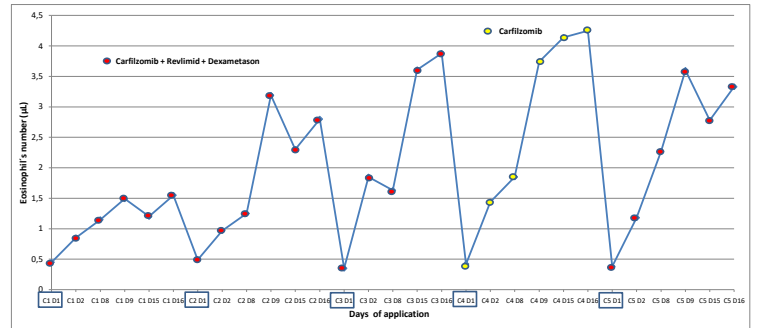

\section{Hosted file}

Figure 2A- Case report.doc available at https://authorea.com/users/345391/articles/471631eosinophilia-associated-with-the-use-of-carfilzomib-in-a-patient-with-multiple-myelomaa-case-report-and-review-of-literature

\section{Hosted file}

Figure 2B- Case report.doc available at https://authorea.com/users/345391/articles/471631eosinophilia-associated-with-the-use-of-carfilzomib-in-a-patient-with-multiple-myelomaa-case-report-and-review-of-literature 